\title{
Contamination Assessment of Durum Wheat and Barley Irrigated with Treated Wastewater through Physiological and Biochemical Effects and Statistical Analyses
}

\author{
Naima Werfelli, ${ }^{1,2,3}$ Rayda Ben Ayed (iD, ${ }^{4}$ Mejda Abassi, ${ }^{3}$ and Zoubeir Béjaoui ${ }^{3}$ \\ ${ }^{1}$ Faculty of Sciences of Tunis, University of Tunis El Manar, El Manar 2092, Tunis, Tunisia \\ ${ }^{2}$ International Center for Environmental Technologies Boulevard Leader Yasser Arafat, Tunis, Tunisia \\ ${ }^{3}$ Forest Ecology Laboratory, National Institute for Research in Rural Water and Forest Engineering, University of Carthage, \\ Ariana 2080, Tunisia \\ ${ }^{4}$ Center of Biotechnology of Sfax, Sfax 3018, Tunisia
}

Correspondence should be addressed to Rayda Ben Ayed; raydabenayed@yahoo.fr

Received 9 November 2020; Revised 7 January 2021; Accepted 1 February 2021; Published 12 February 2021

Academic Editor: Daniel Cozzolino

Copyright ( ${ }^{2} 2021$ Naima Werfelli et al. This is an open access article distributed under the Creative Commons Attribution License, which permits unrestricted use, distribution, and reproduction in any medium, provided the original work is properly cited.

\begin{abstract}
The present work focused on the impact of crop irrigation by treated wastewater (TWW) on soil fertility, in germination, and growth of two species of cereals (T. turgidum and $H$. vulgare). This investigation was conducted at the germination stage (controlled condition) and in pots containing a soil irrigated with wastewater in comparison with controlled soil. Germination rate, vigor index, seedling growth, total fresh mass, chlorophyll content, proline, ascorbate peroxidase (APX), guaiacol peroxidase (GPX), and catalase (CAT) activities were measured. Similar effects were shown on both species which emphasize the important role of antioxidant enzymes in the defense against oxidative stress induced by prolonged reuse of TWW. The disturbing effect of the reuse TWW on soil fertility, germination, and development of young plants (T. turgidum and H. vulgare) was linked to the presence of micropollutants in TWW. Data were analyzed by R language using a nonparametric statistical hypothesis test. These have caused the disorganization of many physiological mechanism targets, especially growth disorders observed under different abiotic stress conditions. In conclusion, high salt and heavy metal concentrations contained in the TWW are the major constraints related to the reuse of TWW. Hence, repetitive irrigation with this water can induce, at long term, soil contamination which can limit plant production and crop contamination.
\end{abstract}

\section{Introduction}

According to many international environmental agencies, such as the World Resource Institute (WRI) or World Conservation Union (WCI) and the Population Action International (PAI), global consumption of water in recent past years has increased by sixfold. Hence, the global water requirement rises up more intensively than the world population's growth. Furthermore, the 2018 edition of the United Nations World Water Development Report [1] predicted that clean water scarcity by the 2050 will affect the life of an estimated 6 billion people by that year [2]. Indeed, water resources have been considered as renewable and unlimited and were able to meet the needs of all generations regardless of water consuming activities. However, water resources are nonrenewable and are nowadays threatened or even exhausted across several regions of the world.

As a consequence of the increased demand on freshwater, anthropogenic activities generate a large amount of wastewater. Hence, large quantities of used water will be recirculated in the environment as waste which is, in the majority of cases, contaminated by different dissolved or particulate substances. However, in many countries, especially in arid and semiarid regions, where freshwater resources are very limited, it has become inevitable to reuse treated wastewater in several activities such as agriculture. In the USA, for example, the irrigation of crops with treated wastewater is an ancient practice that began since the first 
half of the last century, precisely since 1930 in the Arizona and Texas [3]. Agricultural valorization of treated wastewater is maintained today to irrigate crops such alfalfa, citrus, cotton, vegetables, wheat, and others species [4]. Hence, the same authors published that the Northern Salinas Valley of Monterey and California currently supplies recycled water for the irrigation of approximately 12.000 acres of crops eaten raw.

Although it is reliable and would resolve, at least partially, the lack of water for crop irrigation, the reuse of treated wastewater may induce other contamination problems of soil and edible plants with different toxic substances [5]. For this reason, several physicochemical analyses of TWW, of soil, and the physiological behavior of irrigated species must be verified before the use of this water in agriculture. These analyses must be related to (1) the concentrations of micropollutants as heavy metals and dangerous microbes, (2) the capability of crops to tolerate and accumulate the putative existing pollutants, (3) the characteristics of soil, essentially its capability to adsorb the pollutants and their availability to root absorption, and (4) the requirement to avoid deep percolation losses that could lead to groundwater contamination [6]. Hence, the first criterion of evaluation could eliminate from agricultural uses the wastewater coming from industrial sites liberating divers dissolved pollutants essentially heavy metals [7].

Municipal wastewater may contain a number of toxic heavy metals especially that collected from many small and informal industrial sites which are directly discharged into the common sewer system. Some of them may be removed during the treatment process, but the majority will persist and present ecotoxicity problems. Thus, before their use in irrigation, municipal wastewater should be checked for trace element toxicity hazards.

In this context, environmentalists have determined thresholds for concentrations of toxic metals in treated wastewater that should not be exceeded. These thresholds take into consideration the degree metal toxicity. According to the wastewater quality guidelines for agricultural use [8], the concentrations of $\mathrm{Cd}, \mathrm{Zn}, \mathrm{Al}, \mathrm{Cu}, \mathrm{Ni}$, and $\mathrm{Co}$ in treated wastewater used in agriculture must not exceed, respectively, $0.01,2.0,5.0,0.2,0.2$, and $0.05 \mathrm{mg} / \mathrm{L}$ [8]. Nevertheless, although all these claims are considered, the continuous irrigation of crops with TWW could induce, in the long or medium term, contamination of soils and plants by heavy metals [9]. Hence, Hussain et al [10] suggested that, for several vegetables such as carrot (Daucus carota subsp. sativus), radish (Raphanus sativus), and spinach (Spinacea oleracea), the consumption of plants irrigated by treated wastewater is free of risks.

With respect to the effect of TWW on plant development, the same results showed that, as compared to plants irrigated with freshwater, the total irrigation of crops with TWW enhanced significantly the vigor (weight, length, leaf number, and root diameter) of plants [10]. The same results were published by El-Nahhal et al. [6] in Chinese cabbage and corn irrigated with TWW. This beneficial effect of TWW on growth was attributed to the enhancement of nutrient (Ca, N, Ca, P, and S) availabilities [11].
In Tunisia, cereals (wheat and barley) are very important for both human and animal nutrition's. However, due scarcity of rainwater, these cereals need additional irrigation, especially during the dry seasons in which the quantities of rainwater do not allow to complete the cycle of the plants. Hence, to ensure better productivity of Triticum turgidum L. and Hordeum vulgare L, farmers used the TWW for additional irrigation.

In this study, we investigated the effects of TWW on germination and growth of Triticum turgidum L. and Hordeum vulgare L. the two most produced and consumed species in Tunisia. Special interest was paid to the accumulation of heavy metals by TWW-irrigated plants. Hence, it is well known that, in plants, heavy metals can induce oxidative stress through generation of reactive oxygen species (ROS). However, plants are equipped with antioxidant machinery that includes enzymatic and nonenzymatic systems, such as ascorbate peroxidase (APX), catalase (CAT), and glutathione reductase (GR). These antioxidants and antioxidant enzymes are up- or downregulated during stress and impart tolerance to plants [12], which could influence other physiological mechanisms of the plant such as transpiration, photosynthesis, respiration, and nitrogen assimilation $[12,13]$.

The specific objective of this study was to evaluate the state of soils irrigated during more than 30 years by TWW in terms of salinity, accumulation of heavy metals, and their impacts on germination, plant development, and the preservation of barley and durum wheat.

\section{Materials and Methods}

2.1. Soils Characteristics and Treatments. Soil samples used in this study (Figure 1) were collected from the horizon 0-20 cm depth from the Borj Touil region (Ariana, Region 1, Tunisia, $36^{\circ} 56^{\prime} 0^{\prime \prime}$ North, $10^{\circ} 8^{\prime} 38^{\prime \prime}$ East) that were irrigated for about 30 years with wastewater treatment (TWW). The control soil was collected, transported, dried, and stored under the same conditions as the contaminated soil. For each soil (contaminated and control soils), three composite samples were formed and were used to determine mineral nutrients and heavy metal concentrations. The quantification of nutrients and heavy metals was performed by ICPOES (PerkinElmer Optima 4300).

2.2. Germination Assay and Culture Condition. Two improved species of barley and durum wheat called "Rihane" and "Maali," respectively, were developed by National Institute of Agricultural Research of Tunisia (INRAT) and registered in the national catalogue of new species. Seeds of both species were sterilized in ethanol $70 \%(\mathrm{v} / \mathrm{v})$ during $2 \mathrm{~min}$ and then with $5 \%$ sodium hypochlorite $(\mathrm{NaOCl})$ solution for $1 \mathrm{~min}$. Seeds were finally washed twice with deionized water. Sterilized seeds of both species were germinated in $15 \mathrm{~cm}$-diameter plastic pots filled with $3 \mathrm{~kg}$ soil each (20 seeds per pot). Uniform seeds were randomly placed on the topsoil, and the soil was then lightly turned to cover the seeds. Two treatments were applied, respectively, 


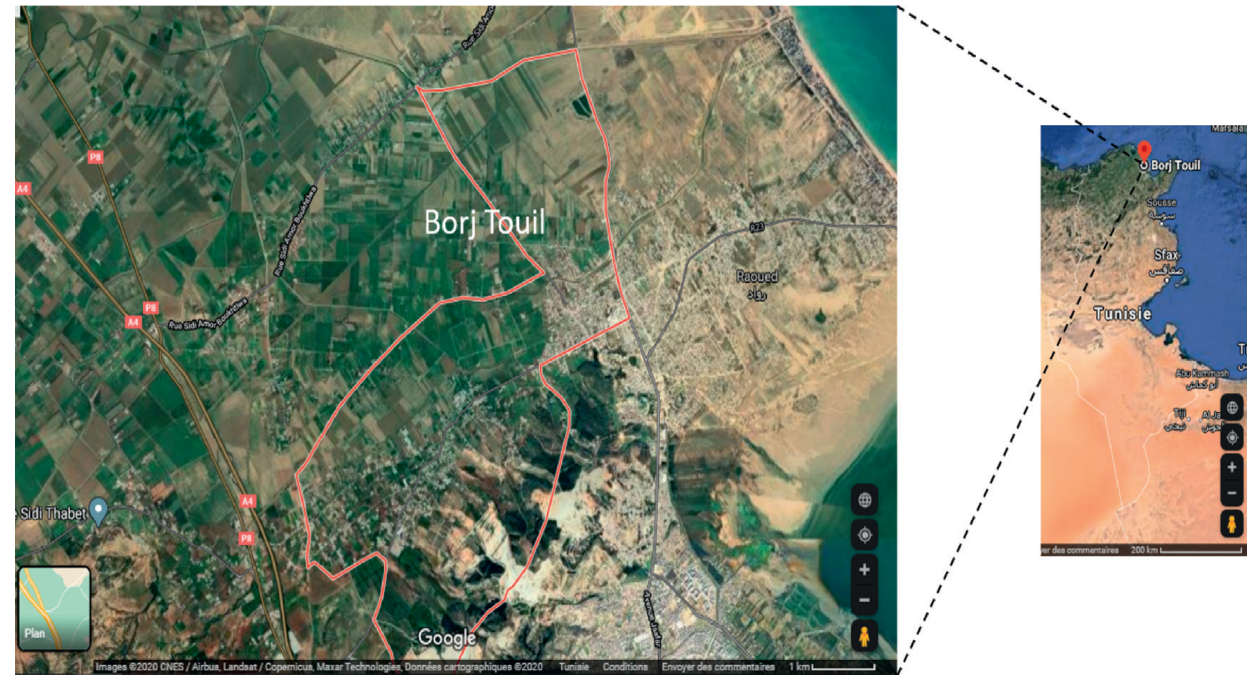

Figure 1: Localized site of Borj Touil Region (Ariana, Region 1, Tunisia, $36^{\circ} 56^{\prime} 0^{\prime \prime}$ North, $10^{\circ} 8^{\prime} 38^{\prime \prime}$ East).

for each species: noncontaminated soil (control) irrigated with tap water and stressed soil irrigated with TWW (treated wastewater). Seeds were considered to have emerged if the shoot had reached at least $2 \mathrm{~mm}$ [14]. The numbers of germinated seeds were counted each day to determine the time necessary to reach the final percentage of germinated seeds. The germination percentage (GP) was calculated as the percentage of germinated seeds 15 days after sowing.

The germination percentage (GP) and vigor index (VI) were estimated as follows:

$$
\begin{aligned}
\mathrm{GP}(\%) & =\left(\frac{\text { seeds germinated }}{\text { total seeds }}\right) \times 100, \\
\mathrm{VI} & =\mathrm{GP}(\%) \times \text { mean of seedling length }(\text { root }+ \text { shoot }) .
\end{aligned}
$$

After one month, only 10 plants remain in each pot, and their culture was continued for another three months. The experiment was conducted in a greenhouse for a period of 4 months. Proper care and maintenance were performed from the starting time of seed sowing to plant harvest.

2.3. Growth and Water Content Measurement. During the harvest, shoots of both species were harvested and successively rinsed three times with cold water and blotted between two layers of filter paper. Roots were carefully removed from the substrate and dipped in a cold solution of $\mathrm{HCl}(0.01 \mathrm{M})$ during $5 \mathrm{~min}$ to remove any external heavy metals adsorbed at the root surface and then rinsed three times with cold distilled water and blotted dry with filter paper. The fresh weight was immediately estimated, and the dry weight was measured after $48 \mathrm{~h}$ of desiccation in an oven at $70^{\circ} \mathrm{C}$. The tissue water content (TWC) was determined as

$$
\operatorname{TWC}\left(\mathrm{mLg}^{-1} \mathrm{DW}\right)=\frac{\mathrm{FW}-\mathrm{DW}}{\mathrm{DW}} \text {. }
$$

2.4. Chlorophyll Content. Averages of four readings were taken with a SPAD-502 chlorophyll meter (Minolta, Japan) on the midportion of the leaf blade. Measurements were taken at midmorning (11:00 am) on single, healthy, and fully expanded leaves.

2.5. Proline and Sugars Soluble Contents. Free proline content was extracted from $100 \mathrm{mg}$ of leaf samples in $3 \%(\mathrm{w} / \mathrm{v})$ sulphosalycylic acid and estimated by using ninhydrin reagent according to the method of Bates et al. [14]. The absorbance of fraction with toluene aspired from liquid phase was read at $528 \mathrm{~nm}$. The concentration of proline was calculated from a standard curve using the following equation: ( $\mu$ g proline in extract $/ 115.5$ ) $/ \mathrm{g}$ sample $=\mu \mathrm{mol} / \mathrm{g}$ FW.

Total soluble sugars were quantified using the anthrone reagent method according to Yemm and Willis [13]. The $20 \mathrm{mg}$ DW homogenate in deionized water was incubated in a water bath at $70^{\circ} \mathrm{C}$ and then centrifuged at $3000 \mathrm{~g}$ for $10 \mathrm{~min} .100 \mathrm{ml}$ of the supernatant was added to $4 \mathrm{ml}$ of anthrone solution $(0.15 \mathrm{~g}$ anthronein and $100 \mathrm{ml} 80 \%$ $\mathrm{H}_{2} \mathrm{SO}_{4}$ ) and incubated in a boiling water bath. The absorbance of the samples was determined spectrophotometrically at $620 \mathrm{~nm}$, and the values obtained were reported to standard curve of glucose to determine the soluble sugar content $\left(\mathrm{mg} \mathrm{g}^{-1} \mathrm{DW}\right)$.

2.6. Electrolyte Leakage and $\mathrm{H}_{2} \mathrm{O}_{2}$. Electrolyte leakage (EL) was measured by using a conductivity meter following the method of Scotti Compos et al [15]. Samples were thoroughly washed with sterile water, kept in closed vials with $20 \mathrm{~mL}$ distilled water, and shaken at $100 \mathrm{rpm}$ on an orbital shaker for $24 \mathrm{~h}$ at room temperature, and electrical conductivity (EC) was determined (C1). Again, samples were kept at $100^{\circ} \mathrm{C}$ for $60 \mathrm{~min}$, and $\mathrm{EC}$ was obtained after attaining equilibrium at $25^{\circ} \mathrm{C}(\mathrm{C} 2)$. Electrolyte leakage was calculated as follows: 


$$
\mathrm{EC}(\%)=\frac{\mathrm{C} 1}{\mathrm{C} 2} \times 100 .
$$

The content of $\mathrm{H}_{2} \mathrm{O}_{2}$ was determined according to the method by Loreto and Velikova [16]. Fresh leaf tissues $(50 \mathrm{mg})$ were homogenized in $3 \mathrm{ml}$ of $1 \%(\mathrm{w} / \mathrm{v})$ trichloroacetic acid (TCA). The homogenate was centrifuged at $12000 \mathrm{xg}$ for $15 \mathrm{~min}$, and $0.5 \mathrm{~mL}$ of the supernatant was added to $0.5 \mathrm{~mL}$ of $10 \mathrm{mM}$ potassium phosphate buffer $(\mathrm{pH}$ 7.0) and $1 \mathrm{~mL}$ of $1 \mathrm{M} \mathrm{KI}$. The absorbance of the supernatant was measured at $390 \mathrm{~nm}$. The content of $\mathrm{H}_{2} \mathrm{O}_{2}$ was calculated by comparison with a standard calibration curve previously made with different concentrations of $\mathrm{H}_{2} \mathrm{O}_{2}$.

2.7. Antioxidant Enzyme Activity. A $0.4 \mathrm{~g}$ sample of fresh tissue (shoot or root) was homogenized in an ice-cooled mortar with $2 \mathrm{~mL}$ of extraction buffer $(100 \mathrm{Mm}$ potassium phosphate $\mathrm{KH}_{2} \mathrm{PO}_{4} / \mathrm{K}_{2} \mathrm{HPO}_{4}(\mathrm{pH})$ ) containing $5 \mathrm{Mm}$ sodium ascorbate and $0.2 \mathrm{Mm}$ EDTA. The homogenate was centrifuged at $6000 \mathrm{~g}$ for $15 \mathrm{~min}$ at $4^{\circ} \mathrm{C}$. The supernatant was used for enzyme determination. Catalase (CAT) activity was assayed spectrophotometrically by monitoring the decline in absorbance at $240 \mathrm{~nm}$ as $\mathrm{H}_{2} \mathrm{O}_{2}$ was consumed, against a plant extract-free blank. Guaiacol peroxidase (GPX) activity was determined according to Fielding and Hall [17] by following the increase in absorbance at $470 \mathrm{~nm}$ due to the polymerization of guaiacol to tetragaïacol in the presence of peroxide. $10 \mu \mathrm{l}$ of enzymatic preparation was added to $2 \mathrm{~mL}$ of guaiacol $(0.5 \%)$ and $10 \mathrm{mM}$ hydrogen peroxide $\left(\mathrm{H}_{2} \mathrm{O}_{2}\right)$ in $\mathrm{K}$-phosphate buffer (10 mM and $\mathrm{pH} 7)$. Ascorbate peroxidase activity (APX activity) was measured according to Nakano and Asada [14] by following the decline in absorbance at $290 \mathrm{~nm}$ as ascorbate was oxidized $\left(R=2.8 \mathrm{mM}^{-1} \mathrm{~cm}^{-1}\right)$ in a reaction solution composed of $50 \mathrm{mM}$ HEPES-NaOH (pH 7.6), $0.22 \mathrm{mM}$ ascorbate, $1 \mathrm{mM}$ $\mathrm{H}_{2} \mathrm{O}_{2}$, and enzyme sample.

2.8. Plant Mineral Status. Dried samples were grounded to a fine powder using a porcelain mortar and pestle. Mineral elements ( $\mathrm{Ca}$ and $\mathrm{Mg}$ ) and heavy metal $(\mathrm{Zn}, \mathrm{Cu}, \mathrm{Pb}$, and $\mathrm{Cd}$ ) were measured, after complete mineralization of shoot tissues in $4 / 1(\mathrm{v} / \mathrm{v}) \mathrm{HNO}_{3} / \mathrm{HClO}_{4}(20 \mathrm{~mL})$ mixture at $100^{\circ} \mathrm{C}$, by atomic absorption spectrophotometry (Spectra AA 220 FS, Varian). Potassium concentrations were determined in the same homogenate by flame spectrometry (Corning 400 flame photometer).

2.9. Statistical Analysis. The obtained results were subjected to variance analysis with SPSS software (Statistical Package for the Social Sciences). For the various measured variables, we presented the differences between applied treatments for both studied species ( $\mathrm{C}$ and TWW). The mean comparison was made according to the Tukey test (HSD) at 5\% significant level. Mean values with standard deviation (mean \pm SD) are shown. R software "wmwpow" package $[18,19]$ was used to study the state of soils irrigated by TWW and their impacts on germination and plant development.
The Wilcoxon nonparametric rank-based approach proposed by Frank Wilcoxon in 1945 [20] was used in this study. Wilcoxon analysis is usually applied to the comparison of two dependent samples and also to test the hypothesis that the median of a symmetrical distribution equals a given constant. As with many nonparametric tests, the distribution-free test is based on ranks. The classical Wilcoxon-signed rank test and also important further developments of it were denoted by $D i=Y_{i}-X_{i}, i=1, \ldots, N$ the difference between two paired random variables. The classical Wilcoxon-signed rank test assumes that the differences $D i$ are mutually independent, and $D_{i}, i=1, \ldots, N$ comes from a continuous distribution $F$ that is symmetric about a median $\theta$. All tests were declared statistically significant when $p$ values are $<0.05$.

\section{Results}

3.1. Physicochemical Proprieties of Soil. In our experiment, we used two soils. The first is considered as control (CS) and was collected from superficial horizons (0 to $20 \mathrm{~cm}$ ) from cultivated field which has always been irrigated by well water, and the second is a soil harvested from a field which is irrigated during 30 years with TWW. The physicochemical characteristics of both used soils are summarized in Table 1. The results showed that control soil showed neutral $\mathrm{pH}$ (6.9), while the TWW soil $\mathrm{pH}$ was slightly alkaline (8.4). The EC was also significantly higher in soil irrigated with treated wastewater than in control soil suggesting the elevated salinity of the treated soil. TWW soil was significantly richer in organic matter, sodium, potassium, and calcium as compared to control soil (Table 1). The concentration of most tested heavy metals $(\mathrm{Pb}, \mathrm{Zn}, \mathrm{Cd}$, and $\mathrm{Cu})$ was also higher in wastewater-treated soil than control soil (Table 1). However, these concentrations were clearly below the maximum admissible concentrations (Table 1).

3.2. Seed Germination. Emergence percentage and vigor index of T. turgidum and $H$. vulgare at different soils irrigation are shown in Figure 2. After 15 days, emergence percentage showed no significant differences from control when both species were irrigated with TWW although germination was still in progress till day 15. In T. turigidum, the highest vigor index (VI) was scored in the control soil compared to TWW-irrigated one (Figure 2). While in $H$. vulgare, the seeds germinated under TWW irrigation had a higher VI compared with control, with no significant differences $(p<0.05)$.

3.3. Growth Parameters. During the first month of treatment, TWW irrigation did not cause visible phytotoxicity to the growth of durum wheat and barley; however, some visual Cd toxicity symptoms with chlorotic areas and wilted leaves appeared at the end of experiment, and this effect is more pronounced in T. turgidum than in H. vulgare. Indeed, in durum wheat species, young leaves showed necrotic spots and older leaves started to fall at the end of experiment (data not shown). 
TABle 1: Physical and chemical characteristics of control soil and wastewater irrigated soil.

\begin{tabular}{lcr}
\hline & Sample soil & TWW-irrigated soil \\
\hline $\mathrm{pH}$ & $\mathbf{6 . 9} \pm 0.2 \mathrm{a}$ & $\mathbf{8 . 4} \pm 0.4 \mathrm{a}$ \\
$\mathrm{C} . \mathrm{E}(\mathrm{mS})$ & $\mathbf{1 . 2} \pm 0.3 \mathrm{~b}$ & $\mathbf{4 . 2} \pm 0.4 \mathrm{a}$ \\
Salinity & $\mathbf{0 . 7} \pm 0.4 \mathrm{~b}$ & $\mathbf{1 . 9} \pm 0.2 \mathrm{a}$ \\
Organic material $(\%)$ & $\mathbf{0 . 7} \pm 0.3 \mathrm{~b}$ & $\mathbf{2 . 1} \pm 0.5 \mathrm{a}$ \\
$\mathrm{K}_{2} \mathrm{O}(\mathrm{ppm})$ & $\mathbf{6 8} \pm 11 \mathrm{~b}$ & $\mathbf{1 3 8} \pm 7 \mathrm{a}$ \\
$\mathrm{Na}^{+}(\mathrm{ppm})$ & $\mathbf{7 . 7} \pm 0.6 \mathrm{~b}$ & $\mathbf{1 9 . 9} \pm 1.2 \mathrm{a}$ \\
$\mathrm{K}^{+}(\mathrm{ppm})$ & $\mathbf{1 . 0} \pm 0.3 \mathrm{~b}$ & $\mathbf{8 . 3} \pm 0.4 \mathrm{a}$ \\
$\mathrm{Ca}^{++}(\mathrm{ppm})$ & $\mathbf{4 . 2} \pm 0.3 \mathrm{~b}$ & $\mathbf{5 . 8} \pm 0.4 \mathrm{a}$ \\
$\mathrm{Pb}(\mathrm{ppm})$ & $\mathbf{0 . 2 4} \pm 0.0 \mathrm{~b}$ & $\mathbf{1 5 . 6} \pm 0.0 \mathrm{a}$ \\
$\mathrm{Cd}(\mathrm{ppm})$ & $<\mathbf{0 . 6} \pm 0.1 \mathrm{~b}$ & $\mathbf{3 . 4} \pm 0.0 \mathrm{a}$ \\
$\mathrm{Zn}(\mathrm{ppm})$ & $\mathbf{0 . 7 2} \pm 0.0 \mathrm{~b}$ & $\mathbf{2 5 8 . 4} \pm 0.0 \mathrm{a}$ \\
$\mathrm{Cu}(\mathrm{ppm})$ & $\mathbf{0 . 8 6} \pm 0.1 \mathrm{~b}$ & $\mathbf{6 8 . 0} \pm 0.1 \mathrm{a}$ \\
\hline
\end{tabular}

Means of four replicates. Bars marked with the same letter are not significantly different at $p<0.05$.

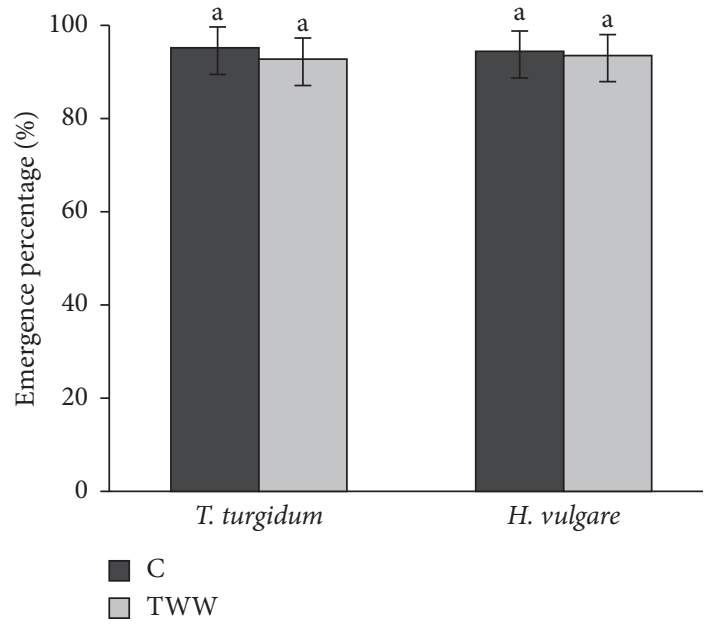

(a)

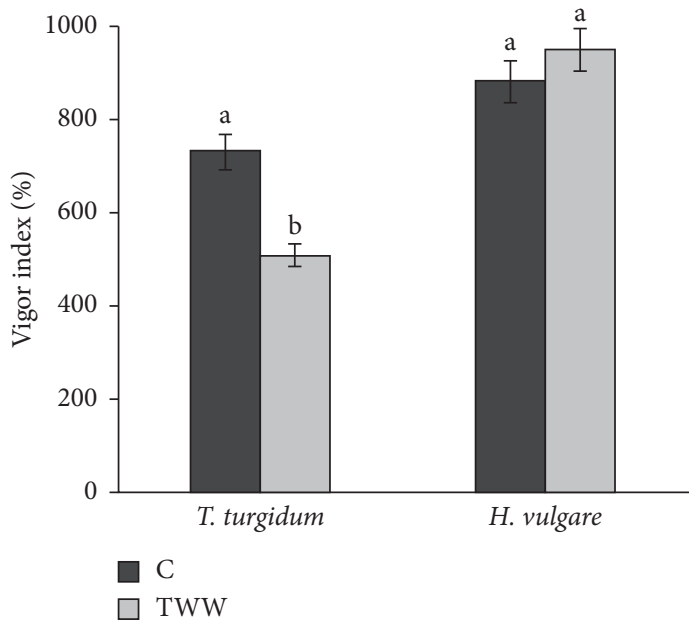

(b)

FIGURE 2: Emergence percentage and vigor index of T. turgidum and H. vulgare leaves cultured in control soils and wastewater irrigated soils. Means of four replicates. Bars marked with the same letter are not significantly different at $p<0.05$.

SPAD value as an expresser for chlorophyll content was determined. Results confirmed that T. turgidum was more sensitive to wastewater irrigation than $H$. vulgare (Table 2). However, in T. turgidum, wastewater irrigation induced a significant decrease in SPAD value $(-45 \%)$, while in H. vulgare, SPAD value exhibited little effect $(-26 \%)$.

Root and shoot lengths of 4 months old seedlings at different soils irrigation are presented in Table 2. Wastewater irrigation significantly decreased shoot and root lengths in T. turgidum plants reaching $16.6 \%$ and $33.78 \%$ of reduction in shoot and root lengths, respectively (Table 2), as compared to control, whereas in $\mathrm{H}$. vulgare, shoot and root length was not significantly changed by wastewater irrigation.

Exposure to different water irrigation caused variable effects on the biomass of both species. The shoot, root, and total dry biomass and RWC values of durum wheat cultured in wastewater-treated soils were decreased by $36 \%, 38 \%$, and $36 \%$, respectively (Table 2 ). In contrast, the depressive effect of wastewater irrigation in shoot and root total dry biomass production in barley was insignificant, and the recorded reduction never exceeded $8 \%, 14 \%$, and $9 \%$, respectively, in shoot, root, and total biomass as compared with a control plant (Table 2).

A significant decrease in relative water content was also obtained from wastewater irrigated durum wheat and barley, and this effect was more pronounced in T. turgidum than in H. vulgare $(-22.5 \%$ and $-5.5 \%$, respectively, compared with control).

3.4. Proline and Soluble Sugar. The results presented in Figure 3 show that proline and soluble sugars were significantly increased in leaves of durum wheat and barley plants exposed to wastewater irrigation, and they were higher in $H$. Vulgare than T. turgidum. Under wastewater irrigation, proline content in T. turgidum and $H$. vulgare leaves increased by $245 \%$ and $350 \%$, respectively, compared with the control (Figure 3). 
TABLE 2: Lengths of shoots and roots and dry biomass of durum wheat and barley on control soil and soil irrigated with wastewater from the pumping water treatment station of CRDA Ariana.

\begin{tabular}{|c|c|c|c|c|c|c|c|}
\hline Soils & $\begin{array}{l}\text { Shoot length } \\
(\mathrm{cm})\end{array}$ & $\begin{array}{l}\text { Root length } \\
(\mathrm{cm})\end{array}$ & $\begin{array}{l}\text { Shoot dry mass } \\
\text { (g) }\end{array}$ & $\begin{array}{l}\text { Root dry mass } \\
\text { (g) }\end{array}$ & $\begin{array}{l}\text { Total dry mass } \\
\text { (g) }\end{array}$ & $\begin{array}{c}\text { Relative water } \\
\text { content }(\%)\end{array}$ & $\begin{array}{l}\text { SPAD } \\
\text { values }\end{array}$ \\
\hline \multicolumn{8}{|l|}{ T. turgidum } \\
\hline $\begin{array}{l}\text { Control } \\
\text { soil }\end{array}$ & $7.9 \pm 0.3 a$ & $9.9 \pm 0.7 \mathrm{a}$ & $3.29 \pm 0.3 a$ & $0.61 \pm 0.02 \mathrm{a}$ & $3.90 \pm 0.4 \mathrm{a}$ & $89.3 \pm 7.4 a$ & $42.9 \pm 5.4 a$ \\
\hline $\begin{array}{l}\text { WWT } \\
\text { soil }\end{array}$ & $5.4 \pm 0.4 b$ & $8.3 \pm 0.5 b$ & $2.11 \pm 0.1 b$ & $\mathbf{0 . 3 8} \pm 0.01 b$ & $2.50 \pm 0.2 b$ & $69.2 \pm 8.6 \mathrm{a}$ & $23.7 \pm 2.4 \mathrm{~B}$ \\
\hline \multicolumn{8}{|l|}{ H. vulgare } \\
\hline $\begin{array}{l}\text { Control } \\
\text { soil }\end{array}$ & $8.6 \pm 0.25 a$ & $8.6 \pm 0.3 a$ & $2.91 \pm 0.2 \mathrm{a}$ & $0.57 \pm 0.03 a$ & $3.48 \pm 0.3 a$ & $81.2 \pm 11.2 \mathrm{a}$ & $49.8 \pm 7.4 a$ \\
\hline $\begin{array}{l}\text { WWT } \\
\text { soil }\end{array}$ & $9.1 \pm 0.3 a$ & $9.2 \pm 0.7 \mathrm{a}$ & $2.68 \pm 0.1 \mathrm{a}$ & $0.49 \pm 0.04 a$ & $3.17 \pm 0.2 \mathrm{a}$ & $76.8 \pm 9.40 b$ & $36.7 \pm 3.4 \mathrm{~b}$ \\
\hline
\end{tabular}

Means of four replicates. Bars marked with the same letter are not significantly different at $p<0.05$.

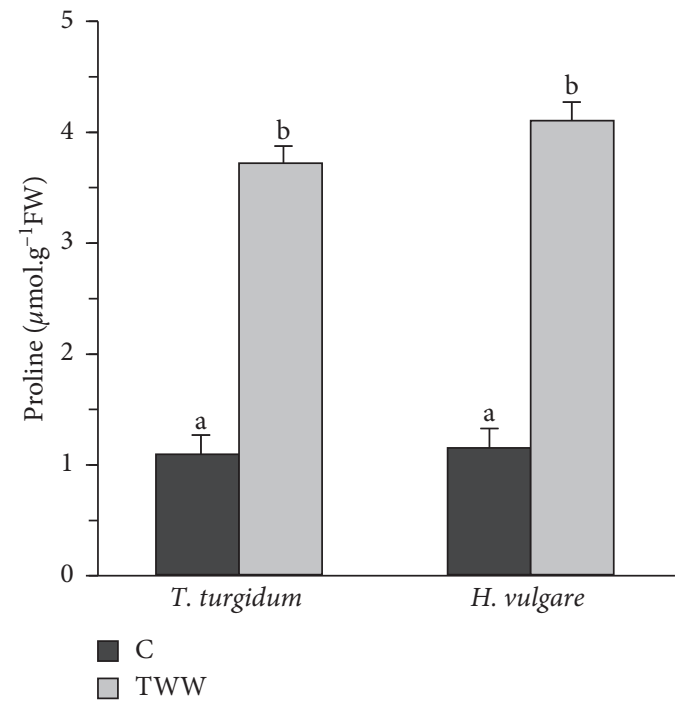

(a)

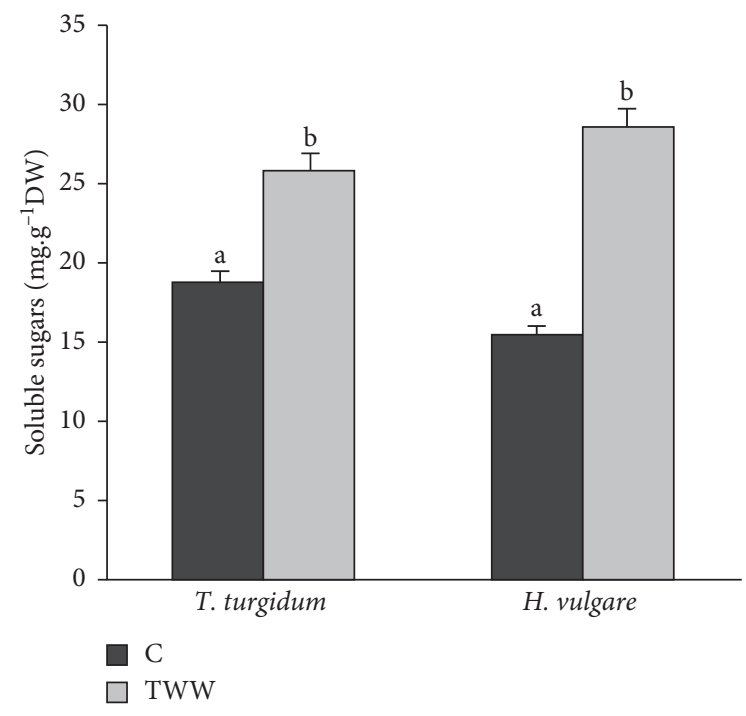

(b)

Figure 3: Proline and soluble sugars of T. turgidum and H. vulgare leaves cultured in control soils and wastewater irrigated soils. Means of four replicates. Bars marked with the same letter are not significantly different at $p<0.05$.

Soluble sugars behaved similarly to proline, reaching $38.5 \%$ and $86.2 \%$ of accumulation for $T$. turgidum and H. vulgare (Figure 3), respectively, as compared to control.

3.5. Electrolyte Leakage and $\mathrm{H}_{2} \mathrm{O}_{2}$ Content. The effects of wastewater irrigation on percentage of electrolyte leakage and $\mathrm{H}_{2} \mathrm{O}_{2}$ content in durum wheat and barley leaves are shown in Figure 4. In both species, the content of $\mathrm{H}_{2} \mathrm{O}_{2}$ and electrolyte leakage (EL) increased severalfold under wastewater irrigation in comparison to the control (Figure 4). However, the highest EL and $\mathrm{H}_{2} \mathrm{O}_{2}$ contents were observed in leaves of $T$. turgidum than those of $H$. vulgare under TWW irrigation.

3.6. Antioxidant Enzyme Activities. Activities of antioxidant enzymes are determined in leaves of durum wheat and barley plants exposed to wastewater irrigation (Figure 5). For both species, wastewater irrigation led to a marked increase in CAT, GPX, and APX activity as compared to control. It is also worth mentioning that activity of all enzymes was significantly $(p<0.05)$ higher in leaves of $H$. vulgare than those of T. turgidum.

3.7. Heavy Metal Accumulation. Average values for element concentrations ( $\mathrm{mg} \mathrm{kg}^{-1}$ dry weight) in shoots and roots of T. turgidum and in $H$. vulgare are presented in Table 3. In general, the concentrations of $\mathrm{Cu}, \mathrm{Zn}, \mathrm{Pb}$, and $\mathrm{Cd}$ increased significantly $(p<0.05)$ in the shoots and roots of both species exposed to TWW irrigation. The data indicate that $\mathrm{Cu}, \mathrm{Zn}, \mathrm{Pb}$, and $\mathrm{Cd}$ accumulated mainly in the roots in higher amounts than that in the aerial parts of both plants. This may indeed reveal different strategies developed by the two species to cope with heavy metals. Whatever the considered species, the concentrations of $\mathrm{Cd}$ and $\mathrm{Pb}$ in shoots were below the detection limit. 


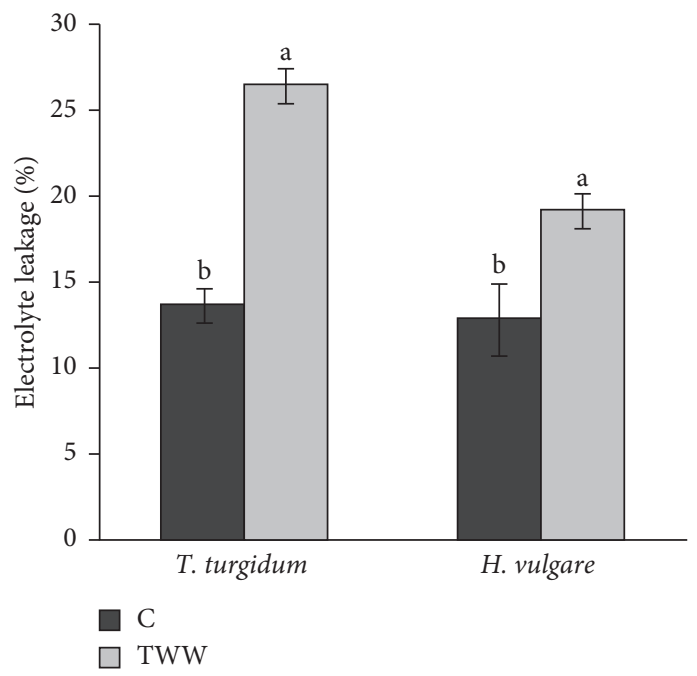

FIgURE 4: Electrolyte leakage and $\mathrm{H}_{2} \mathrm{O}_{2}$ of T. turgidum and $H$. vulgare leaves cultured in control soils and wastewater irrigated soils. Means of four replicates. Bars marked with the same letter are not significantly different at $p<0.05$.

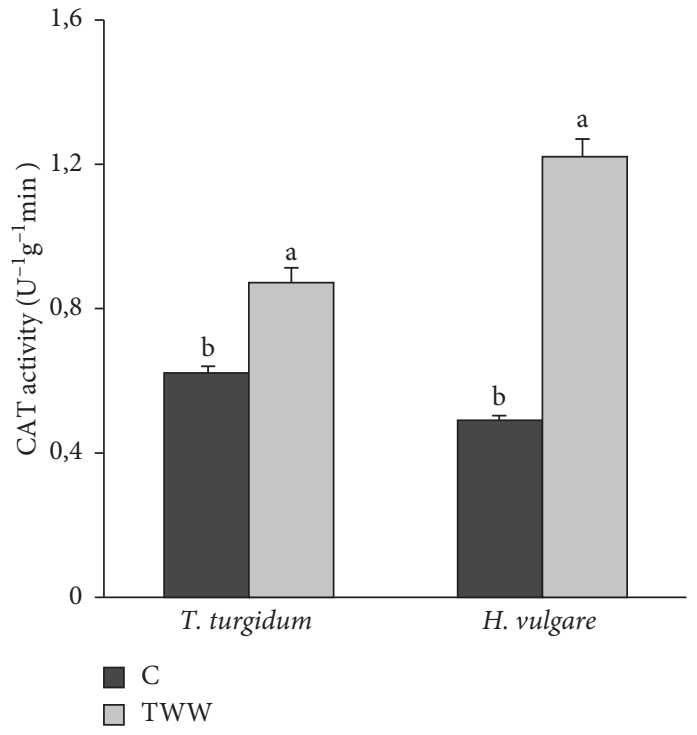

(a)

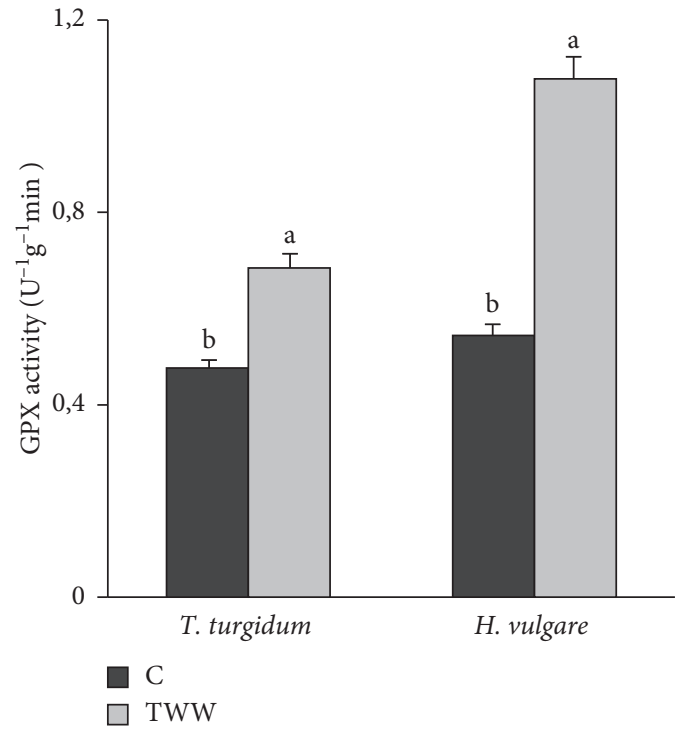

(b)

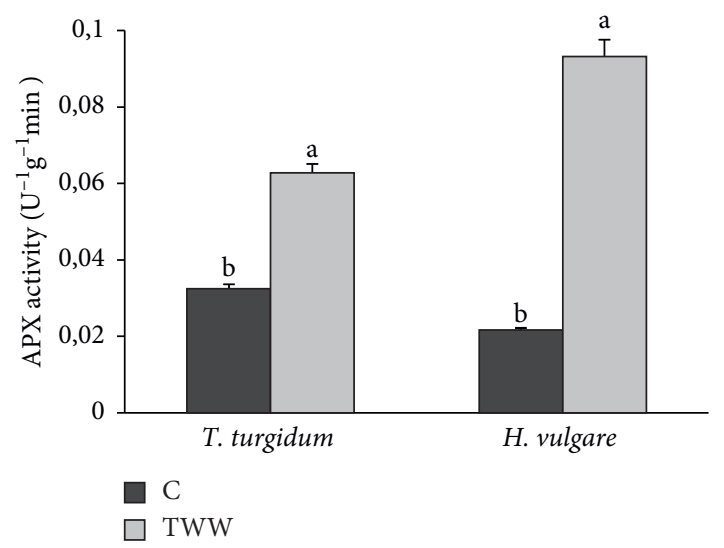

(c)

Figure 5: Activities of CAT (a), GPX (b), and APX (c) in the leaves of T. turgidum and H. vulgare cultured in control soils and wastewater irrigated soils. Means of four replicates. Bars marked with the same letter are not significantly different at $p<0.05$. 
TABle 3: Element concentrations (mg. $\mathrm{kg}^{-1} \mathrm{DW}$ ) in shoot and root of durum wheat and barley on control soil and soil irrigated with wastewater from the pumping water treatment station of CRDA Ariana.

\begin{tabular}{|c|c|c|c|c|c|c|c|}
\hline Soils & $\begin{array}{l}\text { Shoot length } \\
(\mathrm{cm})\end{array}$ & $\begin{array}{l}\text { Root length } \\
(\mathrm{cm})\end{array}$ & $\begin{array}{l}\text { Shoot dry mass } \\
\text { (g) }\end{array}$ & $\begin{array}{l}\text { Root dry mass } \\
\text { (g) }\end{array}$ & $\begin{array}{l}\text { Total dry mass } \\
\text { (g) }\end{array}$ & $\begin{array}{c}\text { Relative water } \\
\text { content }(\%)\end{array}$ & $\begin{array}{l}\text { SPAD } \\
\text { values }\end{array}$ \\
\hline \multicolumn{8}{|l|}{ T. turgidum } \\
\hline $\begin{array}{l}\text { Control } \\
\text { soil }\end{array}$ & $7.9 \pm 0.3 a$ & $9.9 \pm 0.7 \mathrm{a}$ & $3.29 \pm 0.3 a$ & $0.61 \pm 0.02 \mathrm{a}$ & $3.90 \pm 0.4 \mathrm{a}$ & $89.3 \pm 7.4 a$ & $42.9 \pm 5.4 a$ \\
\hline $\begin{array}{l}\text { WWT } \\
\text { soil }\end{array}$ & $5.4 \pm 0.4 b$ & $8.3 \pm 0.5 b$ & $2.11 \pm 0.1 b$ & $\mathbf{0 . 3 8} \pm 0.01 b$ & $2.50 \pm 0.2 b$ & $69.2 \pm 8.6 \mathrm{a}$ & $23.7 \pm 2.4 \mathrm{~B}$ \\
\hline \multicolumn{8}{|l|}{ H. vulgare } \\
\hline $\begin{array}{l}\text { Control } \\
\text { soil }\end{array}$ & $8.6 \pm 0.25 a$ & $8.6 \pm 0.3 a$ & $2.91 \pm 0.2 \mathrm{a}$ & $0.57 \pm 0.03 a$ & $3.48 \pm 0.3 a$ & $81.2 \pm 11.2 \mathrm{a}$ & $49.8 \pm 7.4 a$ \\
\hline $\begin{array}{l}\text { WWT } \\
\text { soil }\end{array}$ & $9.1 \pm 0.3 a$ & $9.2 \pm 0.7 \mathrm{a}$ & $2.68 \pm 0.1 \mathrm{a}$ & $0.49 \pm 0.04 a$ & $3.17 \pm 0.2 \mathrm{a}$ & $76.8 \pm 9.40 b$ & $36.7 \pm 3.4 \mathrm{~b}$ \\
\hline
\end{tabular}

Means of three replicates. Bars marked with the same letter are not significantly different at $p<0.05$.

TWW irrigation resulted in a significant decrease in T. turgidum shoot and root Fe concentrations. However, in $H$. vulgare, TWW induced a significant decrease only of root Fe concentrations.

\section{Discussion}

To evaluate plant resistance to different constraints, many physiological and biochemical parameters as plant biomass production, relative water content, chlorophyll, proline and soluble sugars contents, and antioxidant enzymes are commonly used. In fact, these parameters are good indicators of the global state of the plants and reflect the equilibrium between the water of irrigation and soil qualities. The perimeter of Borj Touil has been irrigated by the TWW for more than 30 years [20]. However, due to a lack of follow-up, the soil physicochemical proprieties in irrigated area were unknown before this study. The purpose of this study was, therefore, to evaluate the state of soils irrigated by the TWW in terms of salinity, accumulation of HMs, and their impact on the yield of both cultivated cereals (durum wheat and barley). We showed that the chemical status of TWW-irrigated farmland (Table 1 ) shows that salinity $(\mathrm{Na}$ excess) and the presence of some $\mathrm{HMs}(\mathrm{Pb}, \mathrm{Ni}$, and $\mathrm{Zn}$ ) represent risk of soil salinisation and pollution [21]. Seed germination, one of the most significant stages in a plant's life, is sensitive to the chemical and physical conditions of the rhizosphere [22]. Hence, we suggest that this excess of ions is essentially related to the pollution of TWW that was used for irrigation and chemical fertilizers. The qualities of the soil and the irrigation water certainly have an effect on the biochemical properties and the yield of the crops. The totality of the obtained results constitutes a first step to understand the possible impact of this agricultural practice consisting on the irrigation with TWW on plant productivity and food quality. In fact, salinity and heavy metals in soil could be considered as major abiotic constraints which were responsible for yield loss in the most crops [23]. These stresses are generally responsible for morphological, physiological, biochemical, and molecular changes that negatively affect plant growth and productivity [21]. Our results indicate that the seed germination of both cereals (barley and durum wheat) was slightly increased in soil irrigated with TWW as compared to that conducted in control soil irrigated with tap water suggesting that the irrigation by TWW improved germination [23]. The positive impact of TWW irrigation on the germination process could be attributed to the amelioration of soil water retention and the fertilizing effect [24]. However the research of AL-Tabbal and Ammary showed negative effect of wastewater reuse on germination of barley and onion [25] In addition, TWW induced reverse effects on plant growth, characterized by reduced root and shoot development, as well as plant biomass particularly in T. turgidum. Although concentrations of HM in TWW used for irrigation have low admissible level, such continuous irrigation can in the long term lead to the accumulation of $\mathrm{HM}$ and increasing salinity in the soil upper layers of soil [26]. In addition, salt $(\mathrm{Cl}$ and $\mathrm{Na})$ and heavy metals $(\mathrm{Cd}, \mathrm{Cu}$, $\mathrm{Ni}$, and $\mathrm{Pb}$ ) accumulation in soil irrigated with treated wastewater could disrupt mineral nutrients and water uptake by plants, inhibit photosynthesis [25], reduce enzyme activity, damage cell membranes, limit biosynthesis of metabolites [27], and consequently decrease plant growth and yield [28]. The relative water content of leaves and roots provides information on the relative turgidity of tissues and is one of the criteria used to evaluate abiotic stress tolerance. It is related to the ability of the plant to maintain a level of tissue hydration [29]. After 60 days, the TWW diet resulted in significant reduction in water content in T. turgidum and H. vulgare (Figure 4). According to Kicheva et al. [30], the decrease in the relative water content would result in stomatal closure and limitation of photosynthesis. Also, the use of TWW induced a reduction in chlorophyll content in both species. This reduction could be attributed to an inhibition of the enzymes responsible for the biosynthesis of chlorophyll [31]. In addition, the translocation of HMs to the chlorophyllian apparatus was considered to be the main cause of the adverse effects of metallic stress [32]. Moreover, in the present work, a significant accumulation of proline has been recorded in plants irrigated with TWW. In higher plants, proline is accumulated during abiotic stress, following an increase in its production and/or a reduction in its degradation [33]. According to Monneveux and Nemmar [34], it is a form of adjustment of the osmotic potential. Thus, the 
accumulation of proline is an indicator of stress tolerance [22]. Proline also acts directly as an antioxidant molecule to protect the cell against damage caused by free radicals and act as a chelated metal [35]. In order to reduce the damage caused by oxidative stress, our results showed an increase in CAT, APX, and GPX activity in T. turgidum and H. vulgare. This suggests that the irrigation with TWW is responsible for the accumulation of toxic metals and salt responsible for the generation of oxidative state in both tested cereals. For the two studied species (T. turgidum and $H$. vulgare), we showed a positive significant influence of the all element concentrations for both the shoot and the root developed on soil irrigated with wastewater, except for the Fe element.

\section{Conclusion}

Based on the results described above, we conclude that the seed germination/root elongation test can be successfully used for the evaluation of TWW phytotoxicity. We demonstrated also that TWW used in this study could be used as a fertilizer to improve plant growth as consequence of the enhancement of nutrient bioavailability. Nevertheless, we showed that, excepting germination which is increased by TWW, the irrigation with this wastewater induced negative effect on both cereals. The reduction of durum wheat and barley biomass under TWW irrigation could be related to an excessive accumulation of toxic metals. The repeated use of wastewater in agriculture contributes to the accumulation of metals in soils and can induce adverse effects on photosynthesis, growth, and chlorophyll content. This bioaccumulation of toxic elements can influence the nutritional quality of the final product through the possibility of being transferred to the consumer (animal and human). Given the importance of the risks of contamination of the human food chain via plant products and based on our results, the irrigation with TWW must be more controlled to allow the use only for water having lower contents in pollutants. We also recommend that farmers must be aware of the risks that could be generated following repeated irrigation with treated wastewater, even those with metal contents slightly below the standards.

\section{Data Availability}

The data used to support the findings of this study are available from the corresponding author upon request $[36,37]$.

\section{Disclosure}

The authors declare that this research did not receive specific funding.

\section{Conflicts of Interest}

The authors declare that they have no conflicts of interest.

\section{Acknowledgments}

The authors are grateful to the Manel Taamalli Doctor in "Laboratoire des Plantes Extrêmophiles," Centre de
Biotechnologie de Borj-Cédria, BP 901, Hammam-lif 2050, Tunisia, for her help to improve the content of this article on the revision. The authors are also thankful to Tahar Ghnaya, professor at "Laboratoire des Plantes Extrêmophiles," Centre de Biotechnologie de Borj-Cédria, BP 901, Hammam-lif 2050, Tunisia, and Higher Institute of Arts and Crafts of Tataouine, University of Gabes, Rue Omarr Ebenkhattab6029 Zerig-Gabes, Tunisia, for improving the whole manuscript.

\section{References}

[1] UNESCO Digital Library, (n.d.). https://unesdoc.unesco.org/ search/N-EXPLORE-ee0f8848-070d-47db-a978-09cc59d86ae3 (accessed November 4, 2020).

[2] Food and Agriculture Organization, The State of Food and Agriculture Overcoming Water Challenges in Agriculture, Food and Agriculture Organization, Rome, Italy, 2020.

[3] United States Environmental Protection Agency, Water Topics, US EPA, Washington, D.C., USA, 2016, https://www. epa.gov/environmental-topics/water-topics.

[4] Monterey County Water Resources Agency, Salinas Valley Water Project (SVWP), Monterey County Water Resources Agency, Salinas, CA, USA, 2020, https://www.co.monterey.ca. us/government/government-links/water-resources-agency/ projects-facilities/salinas-valley-water-project-svwp.

[5] M. Qadir, D. Wichelns, L. Raschid-Sally et al., "The challenges of wastewater irrigation in developing countries," Agricultural Water Management, vol. 97, no. 4, pp. 561-568, 2010.

[6] I. M. El-Nahhal, S. M. Zourab, F. S. Kodeh et al., "Nanostructured zinc oxide-cotton fibers: synthesis, characterization and applications," Journal of Materials Science: Materials in Electronics, vol. 24, no. 10, pp. 3970-3975, 2013.

[7] J. N. Ihedioha, E. O. Ogili, N. R. Ekere, and C. C. Ezeofor, "Risk assessment of heavy metal contamination of paddy soil and rice (Oryza sativa) from Abakaliki, Nigeria," Environmental Monitoring and Assessment, vol. 191, p. 350, 2019.

[8] Food and Agriculture Organization, Wastewater Quality Guidelines for Agricultural Use, Food and Agriculture Organization, Rome, Italy, 2020, http://www.fao.org/3/t0551e/ t0551e04.htm.

[9] B. A. Anhwange, E. B. Agbaji, C. E. Gimba, and V. O. Ajibola, "Seasonal variations in trace metals contents of some vegetables grown on irrigated farmlands along the bank of river benue within makurdi metropolis," Journal of Natural Science Reserach, vol. 3, no. 2, pp. 74-82, 2013.

[10] A. Hussain, M. Priyadarshi, and S. Dubey, "Experimental study on accumulation of heavy metals in vegetables irrigated with treated wastewater," Applied Water Science, vol. 9, p. 122, 2020.

[11] F. Etchebarne, P. Aveni, J.-L. Escudier, and H. Ojeda, "Reuse of treated wastewater in viticulture: can it be an alternative source of nutrient-rich water?" BIO Web Conferences, vol. 12, Article ID 01009, 2019.

[12] Z. Yahaghi, M. Shirvani, F. Nourbakhsh, and J. J. Pueyo, "Uptake and effects of lead and zinc on alfalfa (Medicago sativa L.) seed germination and seedling growth: role of plant growth promoting bacteria," South African Journal of Botany, vol. 124, pp. 573-582, 2019.

[13] L. S. Bates, R. P. Waldren, and I. D. Teare, "Rapid determination of free proline for water-stress studies," Plant and Soil, vol. 39, no. 1, pp. 205-207, 1973. 
[14] J. L. Fielding and J. L. Hall, "A biolchemical and cytochemical study of peroxidase activity in roots ofPisum sativum," Journal of Experimental Botany, vol. 29, no. 4, pp. 969-981, 1978.

[15] E. W. Yemm and A. J. Willis, "Stomatal movements and changes of carbohydrate in leaves of chrysanthemum maximum," The New Phytologist, vol. 53, no. 3, pp. 373-396, 1954.

[16] A. Abdul-Baki and J. D. Anderson, "Vigor determination in soybean seed by multiple criteria," Crop Science, vol. 13, no. 6, pp. 630-633, 1973.

[17] F. Loreto and V. Velikova, "Isoprene produced by leaves protects the photosynthetic apparatus against ozone damage, quenches ozone products, and reduces lipid peroxidation of cellular membranes," Plant Physiology, vol. 127, no. 4, pp. 1781-1787, 2001.

[18] Y. Nakano and K. Asada, "Hydrogen peroxide is scavenged by ascorbate-specific peroxidase in spinach chloroplasts," Plant Cell Physiology, vol. 22, pp. 867-880, 1981.

[19] G. Shieh, S.-L. Jan, and R. H. Randles, "On power and sample size determinations for the Wilcoxon-Mann-Whitney test," Journal of Nonparametric Statistics, vol. 18, no. 1, pp. 33-43, 2006.

[20] F. Wilcoxon, "Individual comparisons by ranking methods," Biometrics Bulletin, vol. 1, no. 6, pp. 80-83, 1945.

[21] C. Hayet, S. Hakima, and H. Elfil, "Impact of treated wastewater reuse for irrigation purposes inTunisia on crops growth, human health and soil," CPQ Nutrition, vol. 1, p. 6, 2018.

[22] O. Sytar, P. Kumari, S. Yadav, M. Brestic, and A. Rastogi, "Phytohormone priming: regulator for heavy metal stress in plants," Journal of Plant Growth Regulation, vol. 38, pp. 739-752, 2018.

[23] S. Hajihashemi, S. Mbarki, M. Skalicky, F. Noedoost, M. Raeisi, and M. Brestic, "Effect of wastewater irrigation on photosynthesis, growth, and anatomical features of two wheat cultivars (Triticum aestivum L.)," Water, vol. 12, no. 2, p. 607, 2020.

[24] R. K. Rattan, S. P. Datta, P. K. Chhonkar, K. Suribabu, and A. K. Singh, "Long-term impact of irrigation with sewage effluents on heavy metal content in soils, crops and groundwater-a case study," Agriculture, Ecosystems \& Environment, vol. 109, no. 3-4, pp. 310-322, 2005.

[25] S. Hajihashemi, M. Brestic, H. M. Kalaji, M. Skalicky, and F. Noedoost, "Special issue in honour of Prof. Reto J. Strasser environmental pollution is reflected in the activity of the photosynthetic apparatus," Photosynthetica, vol. 58, pp. 529539, 2020.

[26] N. Tzortzakis, C. Saridakis, and A. Chrysargyris, "Treated wastewater and fertigation applied for greenhouse tomato cultivation grown in municipal solid waste compost and soil mixtures," Sustainability, vol. 12, no. 10, p. 4287, 2020.

[27] A. El Moukhtari, C. Cabassa-Hourton, M. Farissi, and A. Savouré, "How does proline treatment promote salt stress tolerance during crop plant development," Frontiers in Plant Science, vol. 11, 2020.

[28] B. Myśliwa-Kurdziel and K. Strzałka, "Influence of metals on biosynthesis of photosynthetic pigments," in Physiology and Biochemistry of Metal Toxicity and Tolerance in, M. N. V. Prasad and K. Strzałka, Eds., Springer, Dordrecht, Netherlands, pp. 201-227, 2002.

[29] A. Butarewicz, S. Rosochacki, and E. Wrzaszcz, "Toxicity of sewage from industrial wastewater tratment plants," Journal of Ecological Engineering, vol. 20, no. 2, pp. 191-199, 2019.
[30] M. I. Kicheva, T. D. Tsonev, and I. P. Popova, "Stomatal and nonstomatal limitations to photosynthesis in two wheat cultivars subjected to water stress," Photosynthesis Czech Repubublic, vol. 30, no. 1, pp. 107-116, 1995, https://agris.fao. org/agris-search/search.dorecordID $=\mathrm{CZ} 9401114$.

[31] M. Mkhinini, I. Boughattas, S. Hattab, C. Amamou, and M. Banni, "Effect of treated wastewater irrigation on physiological and agronomic properties of beans Vicia faba," International Journal of Environment, Agriculture and Biotechnology (IJEAB), vol. 3, no. 4, 2018.

[32] P. Ahmad, M. Sarwat, N. A. Bhat, M.. Rafiq Wani, A. Gul Kazi, and L.- Son Phan Tran, "Alleviation of cadmium toxicity in Brassica juncea L. (Czern. \& Coss.) by calcium application involves various physiological and biochemical strategies," Plos One, vol. 10, no. 1, Article ID e0114571, 2015.

[33] C. Kaya, M. Ashraf, M. N. Alyemeni, and P Ahmad, "Responses of nitric oxide and hydrogen sulfide in regulating oxidative defence system in wheat plants grown under cadmium stress," Physiologia Plantarum, vol. 168, no. 2, pp. $345-360,2020$.

[34] M. Ozden, U. Demirel, and A. Kahraman, "Effects of proline on antioxidant system in leaves of grapevine (Vitis vinifera L.) exposed to oxidative stress by $\mathrm{H}_{2} \mathrm{O}_{2}$," Scientia Horticulturae, vol. 119, no. 2, pp. 163-168, 2009.

[35] R. EhKhalilzadeh, E. S. AlirezaPirzad, S. Khan, and S. Anwar, "Long-term effect of heavy metal-polluted wastewaterirrigation on physiological and ecological parameters of salicorniaeuropaeal," Journal of Soil Science and Plant Nutrition, vol. 20, pp. 1574-1587, 2020.

[36] K. R. Mollan, I. M. Trumble, S. A. Reifeis et al., "Exact power of the rank-sum test for a continuous variable," 2019, http:// arxiv.org/abs/1901.04597.

[37] J. A. Al-Tabbal and B. Y. Ammary, "Effect of wastewater and greywater reuse on the germination and early growth of barley and onions," Global Nest Journal, vol. 16, no. 5, pp. 998-1005, 2014. 